\title{
The Effects of Different Levels of Citric Acid on Growth Performance, Nutrient Digestibility and Gastrointestinal $\mathrm{pH}$ of Weaned Piglets
}

Shi Wenying, Lu Chunlian, Li Shang, Song Jiachun, Cao Hongzhan

10.18805/IJAR.BF-1432

\begin{abstract}
Background: This study was conducted to evaluate the effects of different levels of citric acid (CA) on the growth performance, nutrient digestibility and gastrointestinal $\mathrm{pH}$ of weaned piglets.

Methods: A total of 120 weaned piglets with an initial BW of $7.15 \pm 0.01 \mathrm{~kg}$, were randomly divided into four groups including control treatment each with three replicates of 10 piglets each. Each group was supplemented with $0.5 \%$ (control group), $1 \%, 1.5 \%$ and $2 \%$ $\mathrm{CA}$ in the basal diet, respectively.

Result: The results showed that the average daily feed intake (ADFI) and average daily gain (ADG) of added $1 \%$ CA group were significantly higher than that of $0.5 \%$ group $(P<0.05)$. Dietary CA significantly improved the utilization rates of crude protein, calcium and phosphorus $(P<0.05)$, while there was no significant difference between adding $1 \%$ and $1.5 \% \mathrm{CA}(P>0.05)$. Compared with the control group, adding CA effectively reduced the $\mathrm{pH}$ of the stomach, duodenum jejunum and ileum contents and adding $2 \% \mathrm{CA}$ were significantly lower than those in other groups $(P<0.05)$. Therefore, the addition of $1.0 \% \mathrm{CA}$ in the diets of weaned piglets is suitable.

Key words: Citric acid, Gastrointestinal pH, Growth performance, Nutrient digestibility, Weaned piglets.
\end{abstract}

\section{INTRODUCTION}

The immune system, digestive system and intestinal flora of weaned piglets are not completely developed, showing low immunity, insufficient gastric acid secretion and poor digestive function. The change of external environment, physical properties and dietary composition of diet after weaning may very easily cause weaning stress syndrome in piglets, which is mainly manifested as increasing diarrhea rate and decreasing growth performance of piglet (Giannenas et al., 2014; Salisbury et al., 2002; WU et al., 2015).

Studies have shown that CA is a type of high-quality natural acidifier which can improve feed flavor, growth performance and nutrient digestibility, decrease the $\mathrm{pH}$ value of gastrointestinal tract, reduce the number of harmful bacteria, increase the number of beneficial bacteria such as lactobacillus and improve the anti-stress ability and immunity of animals (Boling et al., 2000; Luo et al., 2019; $\mathrm{Xu}$ et al., 2018; Zheng et al., 2020; Zhou and Chen et al., 2010). However, in the practice of pig breeding, there are different reports on the amount and effect of CA in the diet of piglets (Huang et al., 2002; Krause et al., 1994; Krishnakumar et al., 2008; Li et al., 2009; Tsiloyiannis et al., 2001), this may be due to differences in basic diet composition, breeding environment and animal species. Therefore, the present study evaluated the effects of different levels of CA on the growth performance, apparent nutrient digestibility and gastrointestinal $\mathrm{pH}$ of weaned piglets in order to give a more theoretical basis for the rational use of $\mathrm{CA}$ in production practices.
College of Animal Science and Technology, Hebei Agricultural University, Baoding, 071001, China.

Corresponding Author: Cao Hongzhan, College of Animal Science and Technology, Hebei Agricultural University, Baoding, 071001, China. Email: chz516@126.com

How to cite this article: Wenying, S., Chunlian, L., Shang, L., Jiachun, S. and Hongzhan, C. (2022). The Effects of Different Levels of Citric Acid on Growth Performance, Nutrient Digestibility and Gastrointestinal $\mathrm{pH}$ of Weaned Piglets. Indian Journal of Animal Research. DOI: 10.18805/IJAR.BF-1432.

Submitted: 24-08-2021 Accepted: 25-11-2021 Online: 06-01-2022

\section{MATERIALS AND METHODS}

This study was conducted in the Yunong livestock breeding farm located in Shijiazhuang and College of Animal Science and Technology, Hebei Agricultural University. The CA monohydrate, the main ingredient is CA, belongs to food additive, the content is $99 \%$, manufactured by Weifang Yingxuan Industry Co., LTD.

A total of 120 piglets which were weaned at $21 \pm 2 \mathrm{D}$ days, with weight of approximately $7.15 \pm 0.01 \mathrm{~kg}$, were supplied from the Yunong Livestock Breeding Farm located in Shijiazhuang and randomly divided into four groups including control treatment each with three replicates of 10 piglets. Each group was supplemented with $0.5 \%$ (control group), $1 \%, 1.5 \%$ and $2 \% \mathrm{CA}$ in the basal diet, respectively. The experiment was carried out for 45 days, including 3 days of pre-feeding trial. The basal diet formula, a corn-soybean basal diet was prepared according to the guiding feeding 
level of the NY/T 65-2004 of China (Xiong and Zhang, 2010) and NRC (2012), as detailed in Table 1.

The ambient temperature of the piggery was controlled at $25-27^{\circ} \mathrm{C}$ and the humidity is maintained at $55-65 \%$. The piggery was cleaned and disinfected regularly. The piglets were fed three times at 7:00, 14:00 and 18:00 every day, with unrestricted intake of food and water. Daily feed consumption and body weight at the beginning and end of the trial were determined to calculate for the average daily feed intake per day (ADFI), average daily gain (ADG) and feed to gain ratio. The fecal samples from the pigs were collected every day from day 39 to 40 for the determination of digestibility. $10 \mathrm{ml} 10 \%$ hydrochloric acid per 100 grams of feces was added to fix the nitrogen. The feeds and feces were oven-dried at $65^{\circ} \mathrm{C}$ to obtain a constant weight and then ground to pass a $1-\mathrm{mm}$ screen and store at $4^{\circ} \mathrm{C}$ for chemical analysis according to the method of AOAC (2012). The CP were estimated by the Kjeldahl method, ether extract (EE) by the Soxhlet ether extraction apparatus, Calcium $(\mathrm{Ca})$ by Potassium permanganate titration, phosphorus $(\mathrm{P})$ by Molybdate yellow colorimetric method and acid insoluble ash(AIA) was described by the GB/T23742(2009). The digestibility of nutrient were calculated as follows:

Apparent nutrient digestibility $(\%)=$

$100 \times\left[1-\frac{\begin{array}{c}\text { Amount of nutrient } \\ \text { in feces }\end{array}}{\begin{array}{c}\text { Amount of a nutrient } \\ \text { in feed }\end{array}} \times \frac{\begin{array}{c}\text { Amount of acid } \\ \text { insoluble ash in feed }\end{array}}{\begin{array}{c}\text { Amount of acid } \\ \text { insoluble ash in feces }\end{array}}\right.$

(Zhou and Chen, 2010)

At the end of the trial, 3 weaned piglets with similar body weight in each group were killed under anesthesia. The stomach, duodenum, jejunum, ileum and cecum were separated with sterile cotton thread and the $\mathrm{pH}$ of gastrointestinal contents were measured with a portable $\mathrm{pH}$ meter. SPSS 22.0 software was used for processing and statistical analysis of the experiment of single factor test data (ANOVA) and Duncan's method was used for multiple comparisons. The test results were expressed as "Mean \pm SE". Statements of statistical significance were tested at the level $P<0.05$ and extremely significant when $P<0.01$.

\section{RESULTS AND DISCUSSION}

\section{Growth performances}

The growth performances are presented in Table 2. The ADFI and ADG of test group 3 were significantly higher $(p<0.05)$ in comparison with the control. However,there was no significantly difference in ADFI in group 1 , group 2 and group 3 and no significantly difference in ADG in group 1 and group 3 . There was no significant difference in feed/gain ratio among all groups $(p>0.05)$.

A previous study has shown that $2 \%$ (Giesting and Easter, 1985), 2\% 3\% (Cronmwell, 1987), 2.5\% (Krause et al., 1994). CA diets increased the ADG of weaned piglets. However, the current study testified that $1 \%$ CA diet had the best performance. But there was no significant difference in ADFI 1\%, 1.5\%. 2\% CA groups. Similar to these findings were the studies by Huang et al. (2002), Wang (2011) and Zheng et al. (2005). The reasons for the inconsistent results among studies are not known but might be the weaning age of piglets, the buffering capacity of the diets, dietary components and the feeding environment.

\section{Apparent nutrient digestibility}

The apparent digestibility values were shown in Table 3. The digestibility of CP increased with the increase in dietary CA levels and there were significant differences among all groups $(p<0.05)$. The digestibility of EE was reduced with the increase in dietary CA level and there was significant lower $(p<0.05)$ in the $2 \%$ CA group in comparison with control and $1 \% \mathrm{CA}$ groups. The digestibility of $\mathrm{Ca}$ and $\mathrm{P}$ were significantly increased with the increase in dietary $C A$ levels $(p<0.05)$, but there were no significantly differences in $\mathrm{Ca}$ and $\mathrm{P}$ digestibility between the $1 \% \mathrm{CA}$ and the $1.5 \% \mathrm{CA}$ groups $(p>0.05), P$ digestibility between the $1.5 \% \mathrm{CA}$ and the $2 \%$ CA groups $(p>0.05)$.

Similar to this result, Debi $\mathrm{M}$ et al. (2010) indicated that supplementation of $0.5 \%, 1.0 \%, 1.5 \%, 2.0 \%$ and $2.5 \% \mathrm{CA}$ in growing rabbit diet improved CP digestibility. Broz et al. (1987) found that adding $0.5 \%, 1.0 \%$ or $2.0 \% \mathrm{CA}$ in the basal diet of weaned piglets could significantly improve feed utilization rate. Cao et al. (2015) reported that adding $0.5 \%$ CA and compound acid $(0.25 \%$ benzoic acid and $0.25 \%$ $\mathrm{CA}$ ) significantly increased $\mathrm{Ca}$ and $\mathrm{P}$ digestibility. Diao et al. (2013) determined that dietary $0.5 \%$ CA significantly increased the digestibility of crude protein, ether extract,

Table 1: Composition and nutrient levels of the basal diets of the weaned piglets (\%).

\begin{tabular}{lccc}
\hline Itemts & Content (\%) & \multicolumn{2}{c}{ Nutrient levels } \\
\hline Corn & 65.00 & $\mathrm{DE} /(\mathrm{kcal} / \mathrm{kg})$ & 3520 \\
Wheat bran & 1.40 & $\mathrm{CP}$ & 18.20 \\
Soybean meal & 11.00 & $\mathrm{CF}$ & 2.50 \\
Expanded soybean & 6.00 & $\mathrm{Ca}$ & 1.22 \\
Fish meal & 2.00 & $\mathrm{TP}$ & 0.27 \\
Fermented soybean meal & 4.00 & & \\
Soy protein concentrate & 2.50 & & \\
Limestone & 0.80 & & \\
Whey powder & 2.50 & & \\
CaHPO & 1.00 & & \\
NaCl & 0.30 & & \\
Soybean oil & 2.00 & & \\
Lys & 0.50 & & \\
Premix & 1.00 & & \\
Total & 100.00 & \\
\hline
\end{tabular}

Note: aPremix provides the following per $\mathrm{kg}$ of the diet; $\mathrm{VB}_{1} 1 \mathrm{mg}$; $V_{B_{2}} 2 \mathrm{mg} ; V_{6} 1 \mathrm{mg} ; \mathrm{VB}_{12} 0.1 \mathrm{mg} ;$ VA 1300 IU; VD 1600 IU; VE 18 IU; $\mathrm{VK}_{3} 0.5 \mathrm{mg}$; nicotinic acid $9 \mathrm{mg}$; Pantothenic acid $10 \mathrm{mg}$;Biotin 0.09 mg; Choline Chloride 360 mg; Cu 3 mg; Zn 50 mg; Fe 60 mg; I 0.12 mg; Mn 2 mg; Se 0.13 mg. 
The Effects of Different Levels of Citric Acid on Growth Performance, Nutrient Digestibility and Gastrointestinal pH of Weaned Piglets

Table 2: Effects of the CA additions on the growth performances and diarrhea rates of the weaned piglets.

\begin{tabular}{|c|c|c|c|c|c|c|}
\hline \multirow[b]{2}{*}{ Items } & \multicolumn{4}{|c|}{ Groups } & \multirow[b]{2}{*}{ SEM } & \multirow[b]{2}{*}{$P$-value } \\
\hline & $\begin{array}{c}\text { Control } \\
0\end{array}$ & $\begin{array}{c}\text { Group } 1 \\
1.0 \%\end{array}$ & $\begin{array}{c}\text { Group } 2 \\
1.5 \%\end{array}$ & $\begin{array}{c}\text { Group } 3 \\
2.0 \%\end{array}$ & & \\
\hline IBW/kg & $7.14 \pm 0.01$ & $7.13 \pm 0.01$ & $7.16 \pm 0.01$ & $7.16 \pm 0.03$ & 0.028 & 0.690 \\
\hline $\mathrm{FBW} / \mathrm{kg}$ & $24.87 \pm 0.09^{c}$ & $27.39 \pm 0.17^{a}$ & $25.75 \pm 0.72^{\mathrm{bc}}$ & $26.43 \pm 0.20^{\mathrm{ab}}$ & 0.549 & 0.010 \\
\hline$A D F I /(g / d)$ & $788.28 \pm 38.58^{b}$ & $897.19 \pm 36.76^{a}$ & $861.04 \pm 4.89^{\mathrm{ab}}$ & $815.61 \pm 22.28^{\mathrm{ab}}$ & 14.511 & 0.111 \\
\hline$A D G(g / d)$ & $454.56 \pm 2.54^{c}$ & $519.41 \pm 4.61^{a}$ & $476.55 \pm 18.84^{\mathrm{bc}}$ & $494.08 \pm 6.19^{\mathrm{ab}}$ & 10.604 & 0.012 \\
\hline$F / G$ & $1.74 \pm 0.09$ & $1.73 \pm 0.08$ & $1.81 \pm 0.06$ & $1.65 \pm 0.02$ & 0.100 & 0.498 \\
\hline
\end{tabular}

Note: Different letters within the same row represent significant difference.

Table 3: Effects of CA additions on the apparent nutrients digestibility of weaned piglets (\%).

\begin{tabular}{lcccccc}
\hline & \multicolumn{5}{c}{ Groups } & \\
\cline { 2 - 6 } Items & Control & Group 1 & Group 2 & Group 3 & SEM & $P$-value \\
& 0 & $1.0 \%$ & $1.5 \%$ & $2.0 \%$ & $0.00 .50 \pm 0.26^{\mathrm{a}}$ & 0.374 \\
$\mathrm{CP}$ & $75.44 \pm 0.34^{\mathrm{d}}$ & $78.87 \pm 0.30^{\mathrm{b}}$ & $77.69 \pm 0.08^{\mathrm{c}}$ & 80.000 \\
$\mathrm{EE}$ & $73.98 \pm 0.62^{\mathrm{a}}$ & $73.56 \pm 0.22^{\mathrm{a}}$ & $72.82 \pm 0.78^{\mathrm{ab}}$ & $71.73 \pm 0.19^{\mathrm{b}}$ & 0.734 & 0.065 \\
$\mathrm{Ca}$ & $63.19 \pm 0.77^{\mathrm{c}}$ & $66.06 \pm 0.52^{\mathrm{b}}$ & $65.60 \pm 0.12^{\mathrm{b}}$ & $68.68 \pm 0.29^{\mathrm{a}}$ & 0.694 & 0.000 \\
$\mathrm{P}$ & $50.07 \pm 1.09^{\mathrm{c}}$ & $54.90 \pm 0.58^{\mathrm{b}}$ & $56.49 \pm 1.13^{\mathrm{ab}}$ & $59.32 \pm 0.98^{\mathrm{a}}$ & 1.378 & 0.001 \\
\hline
\end{tabular}

Note: Different letters within the same row represent significant difference.

Table 4: Effects of the $\mathrm{CA}$ addition on the $\mathrm{pH}$ levels of the contents of the gastrointestinal tracts of weaned piglets (\%).

\begin{tabular}{|c|c|c|c|c|c|c|}
\hline \multirow[b]{2}{*}{ Items } & \multicolumn{4}{|c|}{ Groups } & \multirow[b]{2}{*}{ SEM } & \multirow[b]{2}{*}{$P$-value } \\
\hline & $\begin{array}{c}\text { Control } \\
0\end{array}$ & $\begin{array}{c}\text { Group } 1 \\
1.0 \%\end{array}$ & $\begin{array}{c}\text { Group } 2 \\
1.5 \%\end{array}$ & $\begin{array}{c}\text { Group } 3 \\
2.0 \%\end{array}$ & & \\
\hline Stomach & $3.64 \pm 0.05^{a}$ & $3.26 \pm 0.05^{b}$ & $3.36 \pm 0.04^{b}$ & $2.99 \pm 0.06^{c}$ & 0.073 & 0.001 \\
\hline Duodenum & $5.92 \pm 0.07^{a}$ & $5.82 \pm 0.03^{a b}$ & $5.72 \pm 0.04^{b}$ & $5.51 \pm 0.05^{c}$ & 0.068 & 0.002 \\
\hline Jejunum & $6.44 \pm 0.04^{b}$ & $6.35 \pm 0.01^{b}$ & $6.61 \pm 0.01^{a}$ & $6.14 \pm 0.08^{c}$ & 0.065 & 0.001 \\
\hline Lleum & $7.01 \pm 0.07^{\mathrm{a}}$ & $6.33 \pm 0.05^{\mathrm{b}}$ & $6.91 \pm 0.10^{\mathrm{a}}$ & $5.99 \pm 0.08^{c}$ & 0.111 & 0.001 \\
\hline
\end{tabular}

Note: Different letters within the same row represent significant difference.

calcium and phosphorus of weaned piglets.But this study showed that $2 \%$ CA group had the highest digestibility of ether extract, which was inconsistent with the report by Diao et al.(2013).

\section{Gastrointestinal pH}

As shown in Table 4, The gastrointestinal $\mathrm{pH}$ were significantly reduced with the increase in dietary CA levels $(p<0.05)$, but there were no significantly differences in $\mathrm{pH}$ of stomach contents between the $1 \% \mathrm{CA}$ and the $1.5 \% \mathrm{CA}$ groups ( $p>0.05$ ), $\mathrm{pH}$ of duodenum contents between the $0.5 \% \mathrm{CA}$ and the 1\% CA groups and between the 1\% CA and the $1.5 \% \mathrm{CA}$ groups ( $p>0.05)$, $\mathrm{PH}$ of jejunum contents between the $0.5 \% \mathrm{CA}$ and the $1 \% \mathrm{CA}$ groups, $\mathrm{pH}$ of ileum contents between the $0.5 \% \mathrm{CA}$ and the $1.5 \% \mathrm{CA}$ groups.

Klieviiūt et al. (2016) showed that organic acids had no significant effect on $\mathrm{pH}$ in different parts of the stomach and intestines of rabbits. There were no significant differences in stomach and small intestine $\mathrm{pH}$ of weaned piglets which also supported by Piva et al. (2007) who reported that no effect on gastrointestinal $\mathrm{pH}$ after inclusion of sorbic acid in swine diets. However, Esmaeilipour et al. (2011) reported that adding CA to a low-phosphorus diet in broilers significantly reduced gastrointestinal pH Risley et al. (1992) found that adding 1.5\% CA to corn soybean meal diet of weaned piglets reduced the $\mathrm{pH}$ of ileum contents. The results of this study showed that additions of CA could significantly reduce the $\mathrm{pH}$ levels of gastric, ileal and jejunal contents. The results of different effects of acidifiers on the $\mathrm{pH}$ of gastrointestinal tract contents may be related to the treatment technology and the inclusion level of acidifiers as well as the differences of animal species and individuals.

\section{CONCLUSION}

In the present study, it was found that under the experimental conditions, the addition of $1 \% \mathrm{CA}$ in the diets of weaned piglets in accordance with various indicators and production benefits had effectively improved intestinal development, significantly reduced the $\mathrm{pH}$ level of the gastrointestinal contents and increased the apparent nutrient digestibility in the feed, thereby enhancing the performance of the examined weaned piglets.

\section{ACKNOWLEDGEMENT}

Thanks to the Hebei Provincial Department of Agriculture (HBCT2018110203) for providing financial support for publishing this article. 


\section{REFERENCES}

AOAC, (2012). Official Methods of Analysis (19 th edn.). Association of Official Analytical Chemists, Washington, DC.

Broz, J., Schulze, J. (1987). Efficacy of citric acid as a feed additive in early weaned piglets. Journal of Animal Physiology and Animal Nutrition. 58: 215-223. DOI: 10.1111/j.14390396.1987.tb00166.x.

Boling, S.D., Webel, D.M., Mavromichalis, I., Parsons, C.M., Baker, D.H. (2000). The effects of citric acid on phytate-phosphorus utilization in young chicks and pigs. Journal of Animal Science. 78: 682-689. DOI: 10.2527/2000.783682x.

Cao, S.C., Yang, Y.K., Liu, J. B. (2015). Effects of organic acids on growth performance and intestinal health of weaned piglets. Feed Industry. 36: 47-51. DOI: 10.13302/j.cnki. fi.2015.02.010.

Cromwell, G.L. (1987). Latest research on feed additives for swine discussed. Feedstuffs. 59: 13-16.

Debi, M.R., Islamk, M.S., Akbar, M.A., Ullha, B., Das, S.K. (2010). Response of growing rabbits to different levels of dietary CA. Bangladesh Journal of Animal Science. 39: 125-133.

Diao, H., Zheng, P., Yu, B., He, J.,Mao, X., Yu, J., Huang, Z., Dai, L., Wang, Q., Chen, D. (2013). Effects of benzoic acid on growth performance, serum biochemical indices, nutrient digestibility and digestive enzyme activities of jejunum digesta in weaned piglets. Chinese Journal of Animal Nutrition. 25: 768-777. DOI:10.3969/j.issn.1006267x.2013.04.014.

Esmaeilipour, O., Shivazad, M., Moravej, H., Aminzadeh, S., Rezaian, M., Van Krimpen, M.M. (2011). Effects of xylanase and CA on the performance, nutrient retention and characteristics of gastrointestinal tract of broilers fed low-phosphorus wheat-based diets. Poultry Science. 90: 1975-1982. DOI: $10.3382 / p s .2010-01264$.

Giannenas, I., Papaneophytou, C.P., Tsalie, E., Pappas, I., Triantafillou, E., Tontis, D., Kontopidis, G.A. (2014). Dietary supplementation of benzoic acid and essential oil compounds affects buffering capacity of the feeds performance of turkey poults and their antioxidant status, $\mathrm{pH}$ in the digestive tract, intestinal microbiota and morphology. AsianAustralasian Journal of Animal Sciences. 27: 225-236. DOI:10.5713/ajas.2013.13376.

Giesting, D.W., Easter, R.A. (1985). Response of starter pigs to supplementation of corn-soybean meal diets with organic acids. Journal of Animal Science. 60: 1288-1294. DOI: 10.2527 /jas1985.6051288x.

Huang, S.Q., Fu, L.H, He, C.Q. (2002). Effects of CA on growth of piglets. Animal Science and Veterinary Medicine. 19(7): 32-33.

Klieviiūt, V., Slausgalvis, V., Racevičiut-Stupelien, A., Sasyte, V., Gružauskas, R., Al-Saifi, J., Pankinait, S., Pockevičius, A. (2016). Influence of dietary inclusion of butric and organic acid salt mixture on rabbits' growth performance and development of digestive Tract. Veterinarija ir Zootechnika. 73: 42-46.

Krause, D.O., Harrison, P.C., Easter, R.A. (1994). Characterization of the nutritional interactions between organic acids and inorganic bases in the pig and chick. Journal of Animal Science. 72: 1257-1262. DOI: 10.2527/1994.7251257x.
Krishnakumar, N., Narayanan, R., Gopu, R., Ronald, B.S.M., Bharathidasan, A., Prabhakaran, R. (2008). Effect of citric acid as feed additive in swine starter diet. Indian Journal of Animal Research. 42: 308-309.

Li, B.J., Wang, J.F., BI, Y.G. (2009). Effects of citric acid on growth performance of early weaned piglets. Animal Husbandry and Feed Science. 30: 60-61.

NRC, (2012). Nutrient Requirements of Swine (11 th edn.). National Academy Press, Washington, DC.

Luo, X., Luo, H.I, He, J. (2019). Effects of compound acidifier on performance, immune function and serum biochemical indices of broilers. China Poultry. 41: 65-69. DOI: 10.16372 /j.issn.1004-6364.2019.16.012.

Piva, A., Pizzamiglio, V., Morlacchini, M, Tedeschi, M., Piva, G. (2007). Lipid microencapsulation allows slow release of organic acids and natural identical flavors along the swine intestine. Journal of Animal Science. 85: 486-93. DOI: 10.2527 /jas.2006-323.

Risley, C.R., Kornegay, E.T., Lindemann, M.D., Wood, C.M., Eigel, W.N. (1992). Effect of feeding organic acids on selected intestinal content measurements at varying times postweaning in pigs. Journal of Animal Science. 70:196206. DOI:10.2527/1992.701196x.

Salisbury, J.G., Nicholls, T.J., Lammerding, A.M., Tuinidge, J., Nunn, M.J. (2002). A risk analysis framework for the long-term management of antibiotic resistance in food producing animals. International Journal of Antimicrobial Agents. 20: 153-164. DOI:10.1016/s0924-8579(02)00169-3.

Tsiloyiannis, V.K., Kyriakis, S.C., Vlemmas, J., Sarris, K. (2001). The effect of organic acids on the control of postweaning oedema disease of piglets. Research in Veterinary Science. 70: 281-285. DOI: 10.1053/rvsc.2001.0475.

Wang, X.Q. (2011). Effects of dietary CA on weight gain of weaned piglets. Animals Breeding and Feed. 8: 42-43. DOI: 10.13300 /j.cnki.cn42-1648/s.2011.08.030.

WU, Y., Jing, Z., Zheng, C., Zheng, C., Wang, L., Zhu, G., Yang, X., Wen, X., Ma, X. (2015). Effects of protein sources and levels in antibiotic-free diets on diarrhea, intestinal morphologyÿand expression of tight junctions in weaned piglets. Animal Nutrition. 1: 170-176.

Xiong, B.H. and Zhang, H.F. (2010). Domestic and foreign livestock and poultry feeding standards and feed composition table. China Agricultural Science and Technology Press, Beijing. pp. 1-5.

Xu, Y.T., Liu, L., Long, S.F., Pan, L., Piao, X.S. (2018). Effect of organic acids and essential oils on performance, intestinal health and digestive enzyme activities of weaned pigs. Animal Feed Science and Technology. 235: 110-119. DOI: 10.1016/j.anifeedsci.2017.10.012.

Zheng, G., Zhang, X., Gong, F. (2005). Effects of dietary CA on weaned piglets. Heilongjiang Animal Husbandry and Veterinary Medicine. (01): 24-25. DOI: 10.13881/j.cnki. hljxmsy.2005.01.016.

Zheng, J.T., Feng, G,L., Cao, L., Zhan, H.J., Li, Y.P., Niu, X.Y., Tang, Y.P., Ren, K.L. (2020). Effects of citric acid on cecal microbial diversity and metabolites of Ira meat rabbits. Chinese Journal of Animal Nutrition. 32: 3808-3818.

Zhou, A.G. and Chen, D.V. (2010). Animal Nutrition ( $3^{\text {rd }}$ Edn.). China Agriculture Press, Beijing. pp.148-151. 